\title{
PROSEDUR PEMBIAYAAN MUDHARABAH PADA PT. BANK NEGARA INDONESIA (BNI) SYARIAH, TBK CABANG PADANG
}

\author{
Mayang Sari, Afriyeni \\ Akademi Keuangan dan Perbankan Padang \\ Afriyeni.yen@gmail.com
}

\begin{abstract}
ABSTRAK
Tujuan dari penelitian ini adalah untuk mengetahui prosedur pembiayaan mudharabah yang dilakukan oleh BNI Syariah Cabang Padang. Dalam menganalisa data, penulis menggunakan metode analisa data kualitatif sebagai metode penelitian yang menjelaskan secara deskriptif mengenai prosedur pembiayaan mudharabah pada BNI Syariah Cabang Padang. Kesimpulan Prosedur pemberian pembiayaan mudharabah BNI syariah sebagai berikut: a. Pengajuan permohonan pembiayaan mudharabah. b. Syarat-syarat pembiayaan mudharabah. c. Analisis dan evaluasi pembiayaan mudharabah. d. Keputusan permohonan pembiayaan mudharabah terbagi atas keputusan pembiayaan diterima dan keputusan pembiayaan ditolak, apabila keputusan pembiayaan diterima atau ditolak disampaikan secara tertulis dengan memberikan alasan yang jelas dan bijaksana. e. Akad pembiayaan mudharabah dan Realisasi pembiayaan mudharabah.
\end{abstract}

Kata Kunci: Prosedur Pembiayaan Mudharabah

\section{PENDAHULUAN}

Praktek perbankan berdasarkan prinsip bagi hasil, dilakukan diIndonesia setelah dikeluarkannya Undang-Undang No.7 tahun 1992 telah diperbaharui menjadi Undang-Undang No. 10 Tahun 1998 tentang Dual Banking System, pasal 1 ayat 3 Undang-Undang No.10 Tahun 1998 Pengertian Bank Umum adalah Bank yang melakasanakan kegiatan usaha secara konvensional dan atau berdasarkan prinsip syariah yang dalam kegiatannya memberikan jasa dalam lalu lintas pembayaran, pasal 1 ayat 4 Undang-Undang No. 10 tahun1998 Pengertian BPR adalah Bank yang melaksanakan kegiatan usaha secara konvensional atau berdasarkan prinsip syariah yang dalam kegiatannya tidak memberikan jasa dalam lalu lintas pembayaran.

Undang-Undang No. 21 Tahun 2008 tentang Perbankan Syariah dan PP RI No. 72 Tahun 1992 tentang bank berdasarkan prinsip bagi hasil serta dikeluarkannya fatwa bunga haram dari majelis ulama Indonesia (MUI) tahun 2003. Banyak bank yang menjalankan operasionalnya secara prinsip syariah dengan diperkenalkannya jenis bank dengan prinsip bagi hasil, maka dalam sistem perbankan Indonesia selain bank umum yang kita kenal selama ini, dapat pula memilih kegiatan usaha berdasarkan sistem bagi hasil. 
Perbedaan prinsip perbankan konvensional dengan bank bagi hasil terletak pada sistem bunga. Bank bagi hasil dalam menjalankan operasinya tidak menggunakan sistem bunga sebagai dasar untuk menentukan imbalan yang akan diterima atas jasa pembiayaan yang diberikan. Demikian pula imbalan yang diberikan kepada nasabah atas dana yang dititipkan kepada bank. Penentuan imbalan yang diinginkan dan yang akan diberikan tersebut semata didasarkan pada prinsip bagi hasil.

Pada bank konvensional imbalan didalam penghimpunan dana dari masyarakat dan menyalurkan dana kepada masyarakat dihitung dalam bentuk bunga yang dinyatakan dalam persentase tertentu.

Berdasarkan hukum-hukum syariah tersebut bank syariah lebih mengutamakan unsur kepercayaan didalam pemberian yang dilakukan. Salah satu bentuk pembiayaan bank syariah adalah pembiayaan mudharabah.

BNI Syariah Cabang Padang merupakan salah satu bank syariah di Indonesia yang menjalankan konsep mudharabah berdasarkan PSAK 105. BNI Syariah Cabang Padang memberikan bantuan pembiayaan dalam bentuk pembayaran secara kredit/cicilan dan mempunyai beberapa sistem, prosedur dan persyaratan yang harus dipenuhi oleh calon debitur.

Konsep Mudharabah suatu akad kerja sama antara penyedia dana (shahibul maal) menyediakan modal 100\% dengan manajemen usaha (mudharib) untuk memperoleh hasil usaha sesuai dengan pembagian hasil usaha sesuai dengan porsi (nisbah) yang disepakati bersama pada awal.

Secara teoritis, pemberian pembiayaan yang dilakukan oleh bank syariah tidak memiliki resiko pembiayaan macet yang cukup tinggi karena pembiayaan dilakukan atas hukum-hukum syariah, namun sering kali dalam pelaksanaanya sistem ini masih juga mengandung resiko pembiayaan macet, yang disebabkan nasabah yang mengajukan permohonan pembiayaan ternyata tidak layak diberikan pembiayaan. Dengan demikian diperlukannya informasi yang mendukung pengawasan serta analisa didalam prosedur pemberian pembiayaan.

Penerapan prosedur pembiayaan yang dilakukan oleh BNI Syariah Cabang Padang khususnya pembiayaan Mudharabah telah dilaksanakan sebagaimana mestinya dalam menentukan kriteria layak atau tidak layaknya Mudharib menerima pembiayaan, agar resiko pembiayaan macet dapat diminimalisasi.

Berdasarkan uraian diatas, maka penulis tertarik untuk menganalisa prosedur pembiayaan pada bank BNI Syariah, khususnya sistem pembiayaan mudharabah, maka penulis mengambil judul "Prosedur Pembiayaan Mudharabah Pada BNI Syariah Cabang Padang".

Adapun perumusan masalah yaitu Bagaimana prosedur pembiayaan mudharabah pada BNI Syariah Cabang Padang?

\section{METODE PENELITIAN}

Dalam pengumpulan data dan bahan untuk melakukan penelitian ini di gunakan metode pengumpulan data, sebagai berikut : 


\section{Metode pengumpulan data}

\section{a. Studi Lapangan (Field Research)}

Peninjauan langsung ke objek penelitian yang dipilih untuk memperoleh data primer. Penelitian langsung ke lapangan ini akan dapat membantu penulis untuk melengkapi data yang diperlukan. Adapun cara riset lapangan ini adalah dengan mewawancarai langsung pihak-pihak yang berkepentingan dalam hal ini adalah perusahaan atau instansi yang terkait.

b. Studi Pustaka (Library Research)

Peninjauan langsung ke objek penelitian yang dipilih untuk memperoleh data sekunder. Penelitian ini dilakukan dengan cara mempelajari buku-buku ilmiah dan tulisan-tulisan yang berhubungan dengan pembahasan yang dilakukan.

\section{Metode Analisa Data}

Dalam menganalisa data, penulis menggunakan metode analisa data kualitatif sebagai metode penelitian yang menjelaskan secara deskriptif mengenai prosedur pembiayaan mudharabah pada BNI Syariah Cabang Padang. Metode analisa ditinjau dari dua segi yang berbeda yaitu antara teori dan praktek yang perlu dipertemukan sehingga dapat diketahui sejauh mana pelaksanaanya, apakah perbedaan yang timbul menyangkut prinsip dasar konsep itu sendiri. Dengan menganalisa perbandingan, pertanyaan itu akan terjawab selanjutnya dan hasil analisa itu dipergunakan sebagai dasar pengambilan kesimpulan dan saran.

\section{TINJAUAN LITERATUR}

Menurut Undang - Undang Perbankan No. 10 Tahun 1998, bank adalah badan usaha yang menghimpun dana dari masyarakat dalam bentuk simpanan dan menyalurkannya kepada masyarakat dalam bentuk kredit dan atau bentuk lain dalam rangka meningkatkan taraf hidup rakyat banyak.

Pengertian bank syariah dalam pasal 1 butir 7 UU No. 21 Tahun 2008 tentang perbankan syariah disebutkan : "Bank Syariah adalah Bank yang menjalankan kegiatan usahanya berdasarkan prinsip syariah menurut jenisnya terdiri atas Bank Umum Syariah dan Bank Pembiayaan Rakyat Syariah".

Kemudian menurut Undang-Undang Pokok Perbankan nomor 7 tahun 1992 dan ditegaskan lagi dengan keluarnya Undang-Undang RI nomor 10 tahun 1998 maka jenis perbankan terdiri dari dua jenis Bank yaitu :

\section{Bank Umum}

Yaitu bank yang melaksanakan kegiatan usaha secara konvensional dan atau berdasarkan prinsip syariah yang dalam kegiatannya memberikan jasa dalam lalu lintas pembayaran.

\section{Bank Perkreditan Rakyat ( BPR )}

Yaitu bank yang melaksanakan kegiatan usaha secara konvensional atau berdasarkan prinsip syariah yang dalam kegiatannya tidak memberikan jasa dalam lalu lintas pembayaran.

Menurut Kuncoro dan Suhardjono (2002 : 680), bank memiliki tiga fungsi utama, antara lain:

a. Bank sebagai lembaga yang menghimpun dana masyarakat dalam bentuk simpanan. 
b. Bank sebagai lembaga yang menyalurkan dana ke masyarakat dalam bentuk kredit.

c. Bank sebagai lembaga yang melancarkan transaksi perdagangan dan peredaran uang.

Ketiga fungsi utama tersebut merupakan ruang lingkup kegiatan secara operasional dalam suatu bank.

\section{Fungsi dan Jenis - Jenis Bank}

Fungsi bank yaitu sebagai penghubung (intermediary) antara pihak yang kelebihan dana (surplus) dan pihak yang kekurangan dana (defisit) dan sebagai jasa keuangan perbankan. Di dalam Undang-Undang Perbankan nomor 10 tahun 1998, terdapat beberapa perbedaan jenis perbankan yang dapat dilihat dari segi fungsi, kepemilikan dan dari segi menentukan harga.

Dari segi fungsi perbedaan yang terjadi terletak pada luasnya kegiatan atau jumlah produk yang dapat ditawarkan maupun jangkauan wilayah operasinya. Kemudian kepemilikan perusahaan dilihat dari segi pemilikan saham yang ada serta akte pendiriannya. Sedangkan dari menentukan harga yaitu antara Bank Konvensional berdasarkan bunga dan Bank Syariah berdasarkan bagi hasil.

Jenis perbankan dapat ditinjau dari berbagai segi antara lain:

1. Dilihat dari segi sifatnya

Dalam praktiknya jenis Bank dilihat dari sifatnya dibagi ke dalam dua macam yaitu:

\section{a) Bank Devisa}

Merupakan bank yang dapat melaksanakan transaksi keluar negeri atau yang berhubungan dengan mata uang asing secara keseluruhan, misalnya transfer keluar negeri, inkaso keluar negeri, travelers cheque, pembukaan dan pembayaran Letter of Credit dan transaksi lainnya. Persyaratan untuk menjadi Bank Devisa ini ditentukan oleh Bank Indonesia setelah memenuhi semua persyaratan yang ditetapkan.

b) Bank Non Devisa

Merupakan bank yang belum mempunyai izin untuk melaksanakan transaksi sebagai bank devisa, sehingga tidak dapat melaksanakan transaksi seperti halnya bank devisa, dimana transaksi yang dilakukan masih dalam batas - batas negara.

2. Dilihat dari segi fungsinya

a) Bank Umum

Yaitu bank yang melaksanakan kegiatan usaha secara konvensional dan atau berdasarkan prinsip syariah yang dalam kegiatannya memberikan jasa dalam lalu lintas pembayaran.

b) Bank Perkreditan Rakyat ( BPR )

Yaitu bank yang melaksanakan kegiatan usaha secara konvensional atau berdasarkan prinsip syariah yang dalam kegiatannya tidak memberikan jasa dalam lalu lintas pembayaran.

3. Dilihat dari segi kepemilikannya

Jenis Bank dilihat dari segi kepemilikan adalah sebagai berikut:

a) Bank milik Pemerintah

Yaitu baik akte pendirian maupun modalnya dimiliki oleh Pemerintah, sehingga seluruh keuntungan bank ini dimiliki oleh Pemerintah pula. 
b) Bank milik Swasta Nasional

Yaitu Bank yang seluruh atau sebagian besarnya dimiliki oleh swasta nasional serta akte pendiriannya pun didirikan oleh swasta, begitu pula pembagian keuntungannya diambil oleh swasta pula.

4. Dilihat dari segi cara menentukan harga

Yaitu cara penentuan keuntungan yang akan diperoleh. Yang terbagi dalam 2 kelompok yaitu:

a) Bank yang berdasarkan Prinsip Konvensional

Menetapkan bunga sebagai harga jual, baik untuk produk simpanan seperti giro, tabungan maupun deposito. Demikian pula harga beli untuk produk pinjamannya (kredit) juga ditentukan berdasarkan tingkat suku bunga tertentu. Penentuan harga ini dikenal dengan istilah spread based.

b) Bank yang berdasarkan Prinsip Syariah

Yaitu menerapkan aturan perjanjian berdasarka hukum Islam antara Bank dengan pihak lain baik dalam hal untuk menyimpan dana atau pembiayaan usaha atau kegiatan lainnya. Yang dikenal dengan prinsip Bagi Hasil.

\section{Sumber Dana Bank}

Sumber Dana Bank adalah usaha bank dalam menghimpun dana untuk membiayai operasinya. Asal dana yaitu bersumber dari bank itu sendiri, yang didapat dari setoran modal pemegang saham dan laba pada tahun lalu yang tidak dibagi kepada pemegang sahamnya.

Asal dana berikutnya didapat dari pihak ketiga yaitu berupa tabungan, deposito, giro dan berasal dari lembaga lainnya yaitu pinjaman antar bank, pinjaman bank-bank luar negeri kredit likuiditas Bank Indonesia dan Surat Berharga Pasar Uang (SBPU).

\section{Kegiatan - Kegiatan Bank}

Kegiatan Bank Umum yaitu menghimpun dana masyarakat (funding), menyalurkan dana ke masyarakat (lending), dan memberikan jasa-jasa bank lainnya (service).

Kegiatan Bank Perkreditan Rakyat yaitu menghimpun dana dalam bentuk simpanan tabungan dan simpanan deposito,menyalurkan dana dalam bentuk kredit investasi, kredit modal kerja dan kredit perdagangan.

Adapun larangan bagi Bank Perkreditan Rakyat yaitu tidak menerima simpanan giro, tidak mengikuti kegiatan kliring, tidak boleh melakukan transaksi valuta asing dan tidak boleh melakukan kegiatan perasuransian.

Bank syariah memiliki karakteristik umum dan menjadi landasan dasar bagi operasional bank syariah secara keseluruhan yaitu prinsip bagi hasil (profit sharing). Secara syariah, prinsipnya berdasarkan kaidah mudharabah.

\section{Pengertian Pembiayaan Mudharabah}

Pembiayaan Mudharabah adalah pembiayaan yang dilakukan melalui kerjasama usaha antar dua pihak dimana pemilik modal/bank (shahibul maal) menyediakan modal $100 \%$ sedangkan pihak lainnya menjadi pengelola usaha/ debitur (mudharib) dengan mensyaratkan jenis ataupun bentuk usaha yang dilakukan.

\section{Ketentuan Pembiayaan Mudharabah}

Ketentuan umum dari pembiayaan mudharabah adalah : 
1. Jumlah modal yang disetorkan pada nasabah selaku pengelola modal harus diserahkan tunai, dan dapat berupa uang atau barang yang dinyatakan nilainya dalam satuan uang.

2. Hasil usaha yang dibagi sesuai dengan perhitungan dalam akad, pada setiap bulan atau waktu yang disepakati. Bank selaku pemilik modal menanggung kerugian kecuali akibat kelalaian dan penyimpangan pihak nasabah

3. Bank berhak melakukan pengawasan terhadap pekerjaan, namun tidak berhak mencampuri urusan nasabah.

\section{Prosedur Pembiayaan Mudharabah}

\section{Gambar 1}

\section{Prosedur pemberian pembiayaan mudharabah}

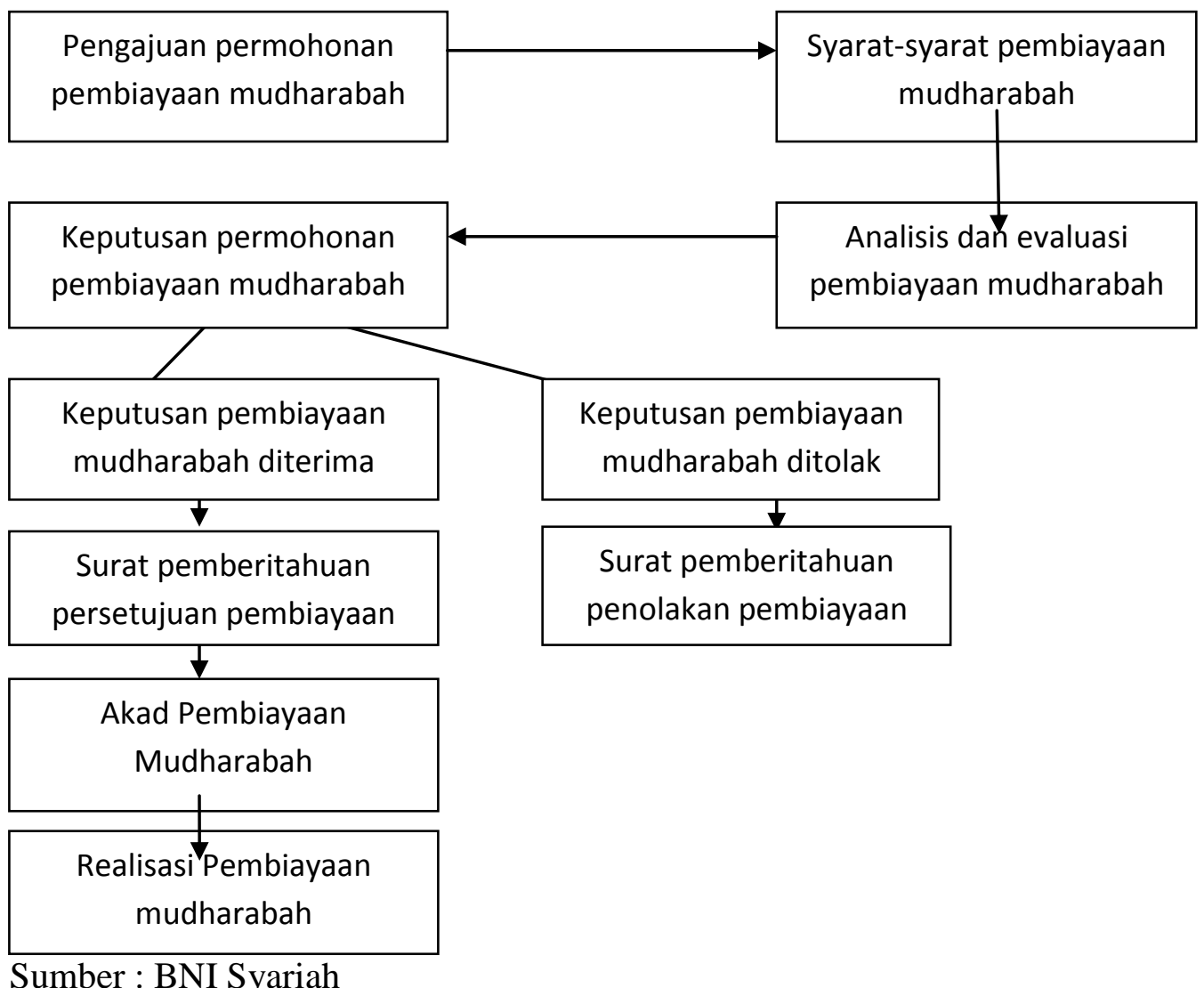

\section{Pengajuan Permohonan Pembiayaan Mudharabah}

Setiap permohonan pembiayaan mudharabah pada BNI Syariah Cabang Padang harus diajukan secara tertulis dengan mengisi formulir surat keterangan permohonan pembiayaan (SKPP) yang telah disediakan serta dilengkapi data yang diperlukan untuk bahan penilaian.

\section{Syarat-syarat Pembiayaan Mudharabah}

1. Usaha nasabah telah sesuai dengan pasar sasaran yang telah ditetapkan BNI Syariah Cabang Padang yaitu :

a. Tidak termasuk dalam daftar hitam Bank Indonesia dan BNI Syariah 
b. Tidak termasuk dalam debitur peminjaman macet sesuai dengan informasi dari Bank Indonesia dan BNI Syariah.

c. Tidak termasuk jenis usaha yang dilarang dan dihindari untuk dibiayai.

2. Usaha nasabah tidak termasuk dalam jenis usaha pemberian pembiayaan yang perlu dihindari yang bersifat spekulatif atau mempunyai resiko tinggi.

3. Tidak melampaui Batas Maksimum Pembiayaan .

Syarat-syarat yang diperlukan untuk pengajuan permohonan pembiayaan mudharabah adalah sebagai berikut :

1. Syarat-syarat Konsumtif kurang dari Rp. 20.000.000

a. Fotokopi KTP Suami dan Istri.

b. Fotokopi Kartu Keluarga dan Akte Nikah.

c. Asli Slip Gaji Pemohon.

d. SK Pengangkatan Pegawai Tetap/Surat Keterangan Masa Kerja.

e. Asli Slip Gaji Istri (bila ada).

f. Nama Ibu Kandung Pemohon.

g. Surat Kuasa, Surat Pernyataan Nasabah.

h. Surat Persetujuan Suami Istri.

i. Daftar barang yang akan dibeli.

j. Asli rekening Listrik dan Telepon Bulan Terakhir.

k. Ditutup Asuransi Jiwa.

2. Syarat-syarat Produktif lebih dari Rp. 20.000.000

a. Fotokopi KTP Suami dan Istri.

b. Fotokopi Kartu Keluarga dan Akte Nikah.

c. Fotokopi Surat Izin Usaha (SIUP, TDP, SITU).

d. Laporan Keuangan Usaha (Laba/Rugi, Neraca) 2 tahun terakhir.

e. Nama dan Alamat Pemasok/Supplier utama minimal 3 (tiga) Pemasok.

f. Nama dan Alamat Pelanggan Utama minimal 3 (tiga) pelanggan.

g. Bukti Kepemilikan Jaminan (SHM, IMB, PBB).

h. Nama Ibu Kandung Pemohon.

i. Biaya Administrasi 1\% dari pembiayaan.

\section{Analisis dan Evaluasi Pembiayaan Mudharabah}

Jika Account Officer dan Pimpinan Cabang menilai bahwa pemohonan pembiayaan mudharabah layak diproses lebih lanjut, maka Account Officer akan menghubungi calon mudharib untuk menentukan kapan akan dilakukan peninjauan langsung kelokasi usaha lokasi jaminan. Jenis-jenis Jaminan Pembiayaan Mudharabah antara lain :

1. Jaminan Materil

Jaminan materil atau agunan dapat berupa benda bergerak dan tidak bergerak.

a. Benda Bergerak

a.1 Kendaraan bermotor yang memiliki nilai marketability, marketability adalah kekuatan barang jaminan itu untuk dijual/ dipasarkan.

a.2 Surat Berharga yakni sertifikat Bank Indonesia (SBI).

a.3 Tabungan pada BNI Syariah Cabang Padang.

a.4 Simpanan Giro pada BNI Syariah Cabang Padang. 
a.5 Benda Bergerak lainnya yang dapat diterima sebagai jaminan pembiayaan sesuai dengan ketentuan BNI Syariah Cabang Padang.

b. Benda tidak bergerak

b.1 Tanah berikut bangunan, status hak atas tanahnya adalah hak milik, hak guna bangunan atau hak pakai yang mempunyai masa berlaku disesuaikan dengan jangka waktu pembiayaan.

b.2 Benda tidak bergerak lainnya yang dapat diterima sebagai jaminan pembiayaan sesuai dengan ketentuan BNI Syariah Cabang Padang.

\section{Jaminan Immateril}

Jaminan immateril dapat berupa jaminan perseorangan (personal guarantee) atau jaminan perusahaan (corporate gurantee). Jaminan immateril mengandung resiko yang sangat tinggi untuk dipergunakan sebagai jaminan pembiayaan dan hanya dapat diterima sebagai jaminan tambahan.

Syarat-syarat agunan yang dijadikan sebagai jaminan pembiayaan adalah :

a. Mempunyai nilai ekonomis (dapat diperjualbelikan secara umum dan jelas) dan nilai marketability.

b. Nilai agunan harus lebih besar dari jumlah pembiayaan yang diberikan.

c. Agunan tersebut tidak berada dalam persengketaan dengan pihak lain.

d. Agunan tersebut tidak ada ikatan jaminan dengan pihak lain.

Setelah diadakan peninjauan lokasi, maka account officer menyusun laporan analisis pembiayaan, laporan data hasil kunjungan, dan laporan hasil peninjauan agunan tanah/kios/kendaraan, dan laporan analisis rasio keuangan calon mudharib.

Laporan-laporan tesebut sebagai bahan pertimbangan untuk memutuskan apakah permohonan pembiayaan tersebut layak atau tidak dibiayai pejabat pemutus. Laporan keuangan calon mudharib beserta analisis yang dilaksanakan oleh pihak bank pada pemohonan pembiayaan mudharabah antara lain sebagai berikut :

a. Identitas dan status perusahaan.

b. Analisis kualitatif

Pada analisis kualitatif meliputi analisis terhadap faktor-faktor intern dan ekstern perusahaan.

c. Analisis kuantatif

Pada analisis kuantitatif yang digunakan laporan keuangan calon mudharib sebagai berikut :

1. Laporan laba/rugi

2. Laporan neraca.

3. Rekonsiliasi Aktiva Tetap.

4. Rekonsiliasi Modal.

5. Pernyataan Kas.

Kelemahan atau resiko yang mungkin pada calon mudharib :

Resiko Pembayaran Pembiayaan, resiko ini dapat ditanggulangi dari jaminan yang diserahkan.

Analisis yang digunakan oleh BNI Syariah adalah analisis $6 \mathrm{C}$ yaitu : 


\section{Analisis Watak (Character)}

Character adalah Keadaan watak/sifat dari calon mudharib, baik dalam kehidupan pribadi maupun dalam lingkungan usaha. Kegunaan dari penilaian ini adalah untuk mengetahui sejauh mana iktikad/kemauan mudharib untuk memenuhi kewajibannya sesuai dengan janji yang ditetapkan.

Untuk menilai karakter ini memang sulit, karena masing-masing manusia mempunyai sifat atau watak yang berbeda satu sama lainnya. Oleh karena itu BNI Syariah harus menguasai praktek umum dapat mengetahui sifat atau watak dari pada calon mudharib dan harus mempunyai pengalaman yang cukup dalam menilai karakter sehingga dapat mengambil kesimpulan tentang karakter calon mudharib dengan benar. Unsur-unsur character yaitu dapat dipercaya, akhlaknya baik, kemauan untuk membayar. Untuk mendapatkan gambaran terntang karakter, BNI Syariah dapat menempuh dengan berbagai cara yaitu meneliti dari daftar riwayat hidupnya, meminta informasi mudharib dari lingkungan sekitarnya, sebagaiman sikap kesehariannya dan lain-lainnya.

2. Analisis Kemampuan (Capacity)

Capacity adalah Kemampuan yang dimiliki calon mudharib dalam menjalankan usahanya guna memperoleh laba yang diharapkan. Kegunaan dari penilaian ini adalah untuk mengetahui/mengukur sejauh mana calon mudharib mampu mengembalikan atau melunasi utang-utangnya secara tepat waktu, dari hasil usaha yang diperolehnya.

Pada BNI Syariah untuk menilai kemampuan calon mudharib dalam membayar pembiayaannya, dapat dihubungkan dengan kemampuannya mengelola bisnis serta kemapuannya mencari laba. Sehingga pada akhirnya akan terlihat kemampuannya dalam mengembalikan pembiayaan. Semakin banyak sumber pendapatan seseorang, maka semakin besar kemampuannya untuk membayar pembiayaan yang diperolehnya. Pengukuran kapasitas dari calon mudharib dapat diperoleh melalui beberapa pendekatan, antara lain :

a. Pendekatan Historis, yaitu menilai nasabah dari sejarah usaha nasabah yang bersangkutan, apakah usahanya banyak mengalami kegagalan atau mengalami perkembangan yang semakin maju dari waktu kewaktu.

b. Pendekatan Finansial, yaitu dengan menilai posisi neraca dan laporan perhitungan laba rugi untuk beberapa periode terakhir untuk mengetahui seberapa besar keuntungan atau kerugian serta resiko usahanya. Unsur-unsur capacity yaitu kemampuan dalam berbisnis, kemampuan dalam mencari keuntungan.

3. Analisis Modal (Capital)

Capital adalah jumlah dana/modal sendiri yang dimiliki oleh calon mudharib. Penilaian atas modal sendiri penting, mengingat pembiayaan bank hanya sebagai pembiayaan dan bukan untuk membiayai seluruh modal yang diperlukan. Modal sendiri juga menjadi pertimbangan bank, sebagai bukti kesungguhan dan tanggung jawab mudharib dalam menjalankan usahanya, karena ikut menanggung resiko terhadap usaha.

Pad BNI Syariah dalam pembiayaan komsumtif tidak memerlukan modal, pada pembiayaan produktif harus mempunyai modal sesuai dengan ketentuan yang ditetapkan oleh BNI Syariah. 
4. Analisis Kondisi dan Prospek Usaha (condition of economy)

Conidition of economy adalah situasi kondisi politik, sosial, economi, dan budaya yang mempengaruhi keadaan perekonomian yang kemungkinan pada suatu saat mempengaruhi kelancaran perusahaan mudharib.

Dalam menilai pembiayan BNI Syariah juga menilai bagaimana kondisi ekonomi sekarang dan dimasa yang akan datang sesuai dengan sektor masingmasing. Dalam kondisi perekonomian yang kurang stabil sebaliknya pembiayaan untuk tidak diberikan terlebih dahulu, harus melihat bagaimana prospek usaha tersebut dimassa yang akan datang. Penilaian terhadap kondisi ini untuk mengetahui sejauh mana kondisi-kondisi yang mempengaruhi perekonomian suatu daerah sehingga dapat memberikan damapak, baik bersifat positif maupun negatif terhadap perusahaan yang akan dibiayai. Unsur-unsur condition yaitu usahanya lancar, mempunyai prospek kedepan yang baik, kondisi perekonomian.

5. Analisis Agunan (collateral)

Collateral adalah barang yang diserahkan mudharib sebagai agunan terhadap pembiayaan yang diterimanya. Collateral harus dinilai oleh bank untuk mengetahui sejauh mana resiko kewajiban financial mudharib kepada bank. Penilaian terhadap agunan ini meliputi jenis, lokasi, bukti kepemilikan, dan status hukumnya.

Pada BNI Syariah untuk menanggung pembayaran pembiayaan macet, calon mudharib umumnya wajib menyediakan jaminan berupa agunan yang berkualitas tinggi dan mudah dicairkan yang nilainya minimal sebesar jumlah pembiayaan yang diberikan kepadanya. Untuk itu sudah seharusnya bank wajib meminta agunan tambahan dengan maksud jika calon mudharib tidak dapat melunasi pembiayaannya, maka agunan tambahan tersebut dapat dicairkan guna menutupi pelunasan atau pengembalian pembiayaan yang tersisa.

6. Constraint

Constraint adalah batasan dan hambatan yang tidak memungkinkan suatu bisnis untuk dilaksanakan pada tempat tertentu. Misalnya pendirian suatu usaha pompa bensin yang disekitarnya banyak bengkel las atau pembakaran batu bara.

Yang sangat diperhatikan dalam analisis $6 \mathrm{C}$ adalah karakter, bila calon penerima pembiayaan dianggap memiliki karakter yang buruk walaupun memiliki penghasilan yang cukup, maka permohonan pembiayaan akan ditolak. Jika jaminan yang besar tidak diikuti dengan kemampuan untuk membayar angsuran, maka permohonan pembiayaan juga akan di tolak.

\section{Keputusan Permohonan Pembiayaan Mudharabah}

Berdasarkan hasil analisis yang dilakukan, maka calon mudharib direkomendasikan untuk mendapatkan pembiayaan sebesar kebutuhan modal kerja. Rekomendasi pemohonan pembiayaan disusun dalam bentuk memorandum pengusulan pembiayaan (MPP).

Bagian Pemasaran bertanggung jawab meneliti dan memastikan bahwa dokumen paket permohonan pembiayaan telah lengkap, masih berlaku, sah dan berkekuatan hukum. Selanjutnya paket dokumen pemohonan pembiayaan diajukan kepada pejabat pemutus sesuai dengan kewenangannya.

Dari hasil analisis setelah melalui proses pengusulan pembiayaan, maka pejabat bank akan memberikan pendapat keputusan pembiayaan diterima atau 
ditolak. Bila disetujui maka akan dibuat surat penegasan atau surat persetujuan dan jika ditolak akan dibuat surat penolakan oleh bagian administrasi pembiayaan.

\section{Analisis prosedur pembiayaan mudharabah}

Setiap tahapan proses pembiayaan mudharabah senantiasa dilakasanakan sebagaimana mestinya dengan menerapkan prinsip kehati-hatian. Hal ini disebabkan karena pembiayaan mudharabah merupakan salah satu produk BNI syariah yang mengandung resiko yang akan merugikan bank dan dapat mempengaruhi kepentingan masyarakat penyimpan dana dan para pengguna jasa perbankan lainnya, walaupun dilaksanakan berdasarkan prinsip syariah. Prinsip kehati-hatian dalam pembiayaan terdapat pada analisis kualitatif dan kuantitatif, termasuk dalam melakukan peninjauan langsung ke lapangan atas kelayakan usaha mudharib untuk dibiayai.

Pemberian Pembiayaan mudharabah harus melalui prosedur yang telah ditetapkan oleh bank untuk menghindari resiko pembiayaan. Prosedur pembiayaan mudharabah ada empat tahap penting yaitu analisis dan evaluasi pembiayaan, syarat-syarat pembiayaan mudharabah, pengusulan pembiayaan, persetujuan pembiayaan. Pejabat pemutus persetujuan pembiayaan mudharabah adalah pengelola pemasaran (PPM), Penyelia Pemasaran Bisnis (PPB) yang bertindak sebagai penganalisa, pengevaluasi dan pembuat memorandum pengusulan pembiayaan (MPP), dan Pimpinan Cabang (PC) yang bertindak sebagai pemutus.

Prosedur pembiayaan mudharabah yang telah dibahas sebelumnya, untuk menentukan apakah calon mudharib layak atau tidak layak menerima pembiayaan analisis dilakukan berdasarkan kriteria yang telah ditetapkan oleh bank. Pemohonan Pembiayaan mudharabah yang diajukan oleh calon mudharib ditolak karena tidak layak dinilai dari segi tujuan penggunaan kredit dan dari segi repayment capacity, calon debitur dinilai belum mampu mengembalikan angsuran pembiayaan mudharabah.

Kriteria mudharib yang dianggap layak menerima pembiayaan mudharabah sebagai berikut :

1. Melengkapi data-data yang diperlukan untuk pengajuan pembiayaan mudharabah baik untuk calon mudharib perorangan atau untuk badan usaha.

2. Usaha mudharib telah sesuai dengan pasar sasaran yang telah ditetapkan BNI Syariah Cabang Padang yaitu :

a. Tidak termasuk dalam daftar hitam Bank Indonesia dan BNI Syariah.

b. Tidak termasuk debitur pinjaman pembiayaan macet sesuai dengan informasi Bank Indonesia dan BNI Syariah.

c. Tidak termasuk jenis usaha yang dilarang dan dihindari untuk dibiayai.

3. Apabila calon mudharib telah menjadi nasabah, selama berhubungan dengan BNI Syariah mempunyai reputasi baik.

4. Analisis rasio keuangan calon mudharib sesuai dengan standar yang telah ditetapkan oleh BNI Syariah.

5. Nilai agunan/jaminan harus lebih besar dari jumlah pembiayaan yang diberikan serta memiliki nilai marketability. 


\section{KESIMPULAN}

1) Pembiayaan Mudharabah adalah pembiayaan yang dilakukan melalui kerjasama usaha antar dua pihak dimana pemilik modal/bank (shahibul maal) menyediakan modal $100 \%$ sedangkan pihak lainnya menjadi pengelola usaha/ debitur (mudharib) dengan mensyaratkan jenis ataupun bentuk usaha yang dilakukan. Ketentuan umum dari pembiayaan mudharabah adalah :

a. Jumlah modal yang disetorkan pada nasabah selaku pengelola modal harus diserahkan tunai, dan dapat berupa uang atau barang yang dinyatakan nilainya dalam satuan uang.

b. Hasil usaha yang dibagi sesuai dengan perhitungan dalam akad, pada setiap bulan atau waktu yang disepakati. Bank selaku pemilik modal menanggung kerugian kecuali akibat kelalaian dan penyimpangan pihak nasabah.

c. Bank berhak melakukan pengawasan terhadap pekerjaan, namun tidak berhak mencampuri urusan nasabah.

2) Prosedur pemberian pembiayaan mudharabah BNI syariah sebagai berikut:

a. Pengajuan permohonan pembiayaan mudharabah.

b. Syarat-syarat pembiayaan mudharabah.

c. Analisis dan evaluasi pembiayaan mudharabah.

d. Keputusan permohonan pembiayaan mudharabah terbagi atas keputusan pembiayaan diterima dan keputusan pembiayaan ditolak, apabila keputusan pembiayaan diterima atau ditolak disampaikan secara tertulis dengan memberikan alasan yang jelas dan bijaksana.

e. Akad pembiayaan mudharabah dan Realisasi pembiayaan mudharabah.

3) Analisis $6 \mathrm{C}$ sebagai dasar pertimbangan pemberian pembiayaan mudharabah di BNI Syariah. Bila calon penerima pembiayaan dianggap memliki karakter yang buruk walaupun memiliki penghasilan yang cukup maka permohonan pembiayaan akan ditolak. Jika jaminan yang besar tidak diikuti dengan kemampuan untuk membayar angsuran maka permohonan pembiayaan juga akan di tolak.

\section{DAFTAR PUSTAKA}

Abdullah, Faisal, 2005. “Manajemen Perbankan”, Edisi Pertama, Cetakan Ketiga, Universitas Muhammadiah Malang, Malang.

Alanshari, F., \& Marlius, D. (2018). Prosedur Pemberian Kredit KPR Pada PT. Bank Tabungan Negara (Persero) TBK Cabang Pembantu Bukittinggi. https://doi.org/10.31227/osf.io/rsfhc

Amelia, L., \& Marlius, D. (2018). Pengendalian Kredit Dalam Upaya Menciptakan Bank Yang Sehat Pada PT. Bank Pembangunan Daerah Sumatera Barat Cabang Utama Padang. https://doi.org/10.31227/osf.io/kpc64

Antonio, Syafi'i, 2001. "Bank Syariah ; Dari Teori ke Praktek”, Gema Insani Press, Jakarta. 
Arifin, Zainul, 2002. “Dasar-dasar Manajemen Syariah”, Cetakan Pertama, Alvabet, Jakarta.

Dendawijaya, Lukman, (2008), “Manajemen Perbankan”, Gramedia Indonesia , Jakarta.

Irmayanto, Juli, 2004.” Bank dan Lembaga Keuangan”, Edisi Revisi, Penerbit Universitas Trisakti, Jakarta.

Ikatan Akuntan Indonesia (IAI), 2003, "Pedoman Akuntansi Syariah Indonesia”, Cetakan Pertama, Penerbit Biro Perbankan Syariah Bank Indonesia, Jakarta.

Institut Bankir Indonesia, 2003." Bank Syariah: Konsep Produk dan Implementasi Operasional”, Cetakan Kedua, Penerbit Djambatan, Jakarta.

Kasmir, (2000), “Manajemen Perbankan”, Edisi Pertama, PT Raja Grafindo Persada,Jakarta.

Orlando, A., \& Susanto, R. (2019). Mekanisme Pencairan Kredit Usaha Rakyat Pada PT. Bank Rakyat Indonesia Unit Lubuk Buaya. https://doi.org/10.31219/osf.io/zuv2y

Prana Yudhi Lubis, Dede,2009. “Analisis Prosedur Pembiayaan Mudharabah pada PT. Bank Negara Indonesia Syariah”, Tbk Cabang Medan.

Shanjaya, A. R., \& Marlius, D. (2017). Peranan Laporan Keuangan Dalam Kebijaksanaan Pemberian Kredit Kepada Calon Nasabah Pada PT. BPR Batang Kapas. https://doi.org/10.31227/osf.io/uxmg6

Seed, Abdullah, 2003." Bank Islam dan Bunga", Cetakan Pertama, Penerbit Pustaka Pelajar, Yogyakarta.

Undang-undang Republik Indonesia Nomor 7 Tahun 1992 jo Nomor 10 Tahun 1998, “Tentang Perbankan”, Sinar Grafika, Jakarta, 2002.

Widayati, R. (2019). Pelaksanaan Prinsip Kehati-Hatian Dalam Pemberian Kredit Konsumtif Pada Bank Nagari Cabang Siteba. https://doi.org/10.17605/OSF.IO/FZVXR

Widayati, R. (2019). Aktivitas Pemberian Kredit Komersil Pada Bank Nagari Cabang Sijunjung. https://doi.org/10.17605/OSF.IO/QTVZ9

Widayati, R. (2019). Pelaksanaan Kredit Pada Bank Perkreditan Rakyat LPN Pasar Baru Durian Sawahlunto. https://doi.org/10.17605/OSF.IO/5HPAB 
Widayati, R. (2019). Aktivitas Pemberian Kredit Usaha Pada PT. Bank Perkreditan Rakyat Batang Kapas. https://doi.org/10.17605/OSF.IO/EDPN4

www.geogle.co.id,Universitas Pendidikan Indonesia. 